\title{
Selected Reference Books of 1999
}

\section{Eileen Mcllvaine}

\begin{abstract}
This article follows the pattern set by the semiannual series initiated by the late Constance M. Winchell more than fifty years ago and continued by Eugene Sheehy. Because the purpose of the list is to present a selection of recent scholarly and general works, it does not pretend to be either well balanced or comprehensive. A brief roundup of new editions of standard works is provided at the end of the articles. Code numbers (such as $\mathrm{AH} 228$ ) have been used to refer to titles in the Guide to Reference Books, $11^{\text {th }}$ ed. (Chicago: ALA, 1996).
\end{abstract}

\section{Publishing}

Kniga: Entsiklopediia; glavnyi redaktor

V. M. Zharkov. Moskva: Bol'shaia Rossiiskaia Entsiklopediia, 1999. 796p. il. (ISBN 5-85270-312-5). LCCN 99223346.

Like the other Russian reference source reviewed in this issue, this one-volume encyclopedia is an outgrowth of an earlier work, Knigovedenie, edited by Nikolai Mikhailovich Sikorskii (Moskva: Bol'shaia Sovetskaia Entsiklopediia, 1981). Its approach to that updating is quite different, however. Rather than simply recording new developments of the two decades since the appearance of its predecessor, it seeks to rework the material in accordance with the changed political and cultural atmosphere in Russia today. The tone of the preceding volume, the editors note, was "excessively idealized. The development of the Soviet book industry was presented there as one of uninterrupted progress" (Ot redkollogii). This volume aims at a more realistic approach, examining moments of difficulty under such headings as "Censorship" and treating hitherto taboo subjects, such as émigré and church literature. Interestingly, however, there still seems to be virtually no information here about the thriving underground samizdat literature of the Soviet period.

The volume consists of a single series of articles, arranged in alphabetical order, covering the whole range of book-related topics: the history of the book and publishing in Russia and other countries, including those that have emerged with the breakup of the Soviet Union; biographies of key Russian and foreign figures in publishing; book arts and the technical, legal, and esthetic aspects of book publishing and bibliography; libraries; publishing

Eileen McIlvaine is Head of Reference in Butler Library at Columbia University; e-mail: mcilvain@columbia.edu. Although it appears under a byline, this list is a project of the reference departments of Columbia University Libraries and notes are signed with the initials of one of the following staff members: Barbara Sykes-Austin, Avery Library; Jennifer Weintraub, Business Library; Mary Cargill, Anice Mills, Robert H. Scott, Junko Stuveras, Sarah Spurgin Witte, Butler Library; Olha della Cava, Lehman Library; Nancy Friedland, Milstein Undergraduate Library; Elizabeth Davis, Music Library. 
houses; organizations; and historical and theoretical articles on a variety of topics. Most articles are brief introductions to their subject, although a core of articles on key topics, including the national surveys, range up to a few pages in length. Most provide at least one or two citations to key literature on the subject. The volume is generously and helpfully illustrated, with many of the reproductions in color. An index of personal names, organizations and institutions, and titles provides additional access to the contents.

Clearly, this title will be an essential reference for anyone wishing to do serious research relating to books and publishing in the Russian context, and it contains much of interest on non-Russian topics as well for those who read Russian. As such, it is an essential acquisition for any serious Russian-language reference collection providing coverage of general, historical or humanities topics.-R.H.S.

\section{Periodical Indexes}

Nitkina, Nina Vasilevna. Russkaia periodicheskaia pechat': ukazateli soderzhaniia, 1728-1995. (The Russian Periodical Press: Indexes, 1728-1995). Sankt-Peterburg: Rossiiskaia Natsional'naia Biblioteka, 1998. 799p. (ISBN 5-8192-0008-X). LCCN 99194392.

Researchers seeking topical bibliographies of periodical articles from Russianlanguage publications have long had a difficult task. Indexing is scattered in a variety of publications, many of them requiring considerable labor to extract the data they contain. An important new source for those seeking to begin such work is this volume representing the latest guide to indexing of Russian periodical literature from the earliest such publication, the 1728 Kratkow opisanie kommentariev Akademii nauk (Brief description of the commentaries of the Academy of Sciences), down to 1995. It is a continuation and supersedes the earlier classic works in this area: Masonov, Ukazateli soderzhaniia russkikh zhurnalov $i$ prodolzhaiushchikhsia izdanii 1735-1970gg
(Indexes of the contents of Russian journals and serial publications, 1755-1970) and its supplement, which covered the period 1971-1985 (AD326). The current work represents a perfecting of that earlier publication, consolidating the material, bringing the coverage up to date, and providing a more solid survey of the material by concluding a much more comprehensive physical examination of the publications listed.

Unlike its predecessors, this volume does not distinguish between pre-1917 and post-1917 publications. Rather, it treats all of its material in two consolidated sections, the first devoted to general and multiple-journal indexes (with listings for more than three titles) and the second to indexing for individual journal titles (including works that index the holdings of two titles together). Entries in the first group are arranged by author (or title for works with more than three authors), and those in the second group by the latest form of the publication's title, with cross-references from earlier forms. (An important and potentially confusing exception, particularly for later users, is that made for the many journals that dropped the adjective Soviet or USSR from their titles in the 1990s or substituted such terms as national or Russian for those words. These are listed under their older titles, and the only indication of the title change is found in a footnote rather than a cross-reference.) Each entry provides basic bibliographic and publication information and, where appropriate, notes indicating years and/or titles covered, parts in which the index was issued, the arrangement of entries, any supplementary indexes provided, and the total number of citations included. The list of individual titles includes entries (and cross-references) for journals covered by collective works in the first section only when those works covered ten or fewer titles. Unfortunately, this means that nowhere in this work can one find a complete list of periodicals covered because notes in the first section also do not provide a list of individual titles when their number exceeds 
ten. Clearly, there is a need here for a supplemental listing of all the titles covered.

Although this work will be essential as the sole listing of its kind, one that no Russian reference collection can afford to be without, it is important to note the areas that it does not cover. As the editors note, indexes to newspapers and annual listings of the contents of a journal volume are not included. Nor are bibliographies of periodical articles that do not clearly represent a more or less full accounting of the contents of particular journals. Finally, although no real statement of the fact is provided in the introduction, there is virtually no coverage of indexes to the contents of émigré or samizdat publications.

Add to this the fact that many of the indexes listed here are often hard to find, particularly in libraries in this country, and it is clear that much still remains to be done to bring the rich bibliography of this field under satisfactory control. The volume presented here, however, represents an important step forward along that road.-R.H.S.

Palmegiano, E. M. Health and British Magazines in the Nineteenth Century. Lanham, Md.: Scarecrow, 1998. 282p. $\$ 59.50$ (ISBN 0-81088-3486-3). LC 983909.

This useful compilation is a listing of articles that appeared in forty-eight general interest titles-the Cornhill Magazine, for instance, and not Lancet. The journals are treated alphabetically, and the citations are listed under them in chronological order; a few have brief, useful annotations. There are separate author and subject indexes. The subject index is quite detailed, but occasionally confusing. The listing under "drowning," for instance, includes a note to "see also specific jobs." Presumably, sailors are at risk, but there is nothing under that heading. The listing under "insanity" also refers the user to "specific forms" but does not list the specific headings used.

The introduction is a useful, though somewhat jargon-filled, summary of Vic- torian attitudes: "the class bias of this discourse permeated other accounts of unwell youths" appears just before the sentence "In myriad words, penmen etched patterns of parents' disinterest in or damage to their progeny," making me long for the clarity and clear thinking of those Victorian penmen.

Scholars of medical history seeking technical information on nineteenth-century British medicine will still rely on the venerable Index-Catalogue of the Library of the Surgeon General's Office (EH47), but this is a useful supplement and should be especially helpful to those working in nineteenth-century social history.-M.C.

\section{Philosophy and Religion}

American Jewish Desk Reference. New

York: Random House, 1999. (Produced by the Philip Lief Group). 642p. il. \$39.95 (ISBN 0-375-40243-8). LCCN 9937154.

This single-volume work includes nearly 900 entries on all aspects of American Jewish history and culture. Sponsored by the American Jewish Historical Society, the notable list of contributors includes Geoffrey Wigoder, who edited the Encyclopaedia Judaica (BC546). The work is divided into fourteen parts covering topics such as the history of Jews in America; rituals and holidays; law; American Zionism; business, education, and intellectual life; sports and games; music, dance, and theater. Within each part, entries are arranged alphabetically and include essays on topics, organizations and movements, and biographies. At the end of each part, a useful bibliography is included for further reading. The topical essays are well written and provide a good overview of the subject. The biographies provide concise introductions to the personality, with a focus on that individual's achievements.

Cross-references are bolded throughout the text, and several of the biographies are supplemented with photographs of the individual. There are several ways to access the contents: a detailed table of contents providing a listing of all of the 
entries and a comprehensive index invaluable for searching specific topics. Also included are two appendixes: a bibliography for works on Jews around the world, and a listing of organizations and resources. Highly recommended for any collection.-N.F.

\section{Edinburgh Encyclopedia of Continental}

Philosophy; Ed. Simon Glendinning. Edinburgh: Edinburgh Univ. Pr., 1999. 685p. \$135 (ISBN 0-7486-0783-8). LCCN GB99-28857.

This encyclopedia, a group work of some sixty contributors and editors, mostly American and British, aims to meet the growing interest in the continental tradition among English-speaking scholars who have tended to favor analytical philosophy and have regarded continental philosophy as a tradition from which they wanted to distance themselves. This interest in continental ideas has been especially strong among literature and language specialists. The encyclopedia's purpose is to provide "the philosophical context of the [Continental] attitudes being explored $\ldots$ by offering a comprehensive and in-depth overview of the central movements, authors and themes that comprise what has become known as the Continental tradition of philosophy" (Pref.).

The encyclopedia follows a topical arrangement devoting a chapter each to (1) classical idealism; (2) philosophy of existence; (3) philosophies of life and understanding; (4) phenomenology; (5) politics, psychoanalysis, and science; (6) The Frankfurt School and critical theory; (7) structuralism; and (8) poststructuralism. Each chapter contains an introduction that gives the overview and then, typically, offers six or seven essays on representative thinkers of various shades and persuasions within the school. Each essay is accompanied by a bibliography of works by and about the philosopher. Subject and name indexes are provided. The encyclopedia can be used as both the survey of European philosophy from Kant to Derrida and the resource to read about a specific philosopher or idea with the help of the subject index. Recommended for college and university libraries as well as public research libraries.-J.S.

\section{Bergman, Jerry. Jehovah's Witnesses: A} Comprehensive and Selectively Annotated Bibliography. Bibliographies and Indexes in Religious Studies, 48. Westport, Conn.: Greenwood, 1999. 351p. \$69.50 (ISBN 0-313-30510-2). LC 98-37845.

As the millennium approaches, there is increasing interest in the various utopian and religious groups; and this extremely detailed bibliography, with its useful introduction and its evenhanded treatment of the history of the movement, should be useful to someone beginning research in the field as well as to religious scholars.

Though there is no subject index, there is a detailed table of contents that should help users locate works on specific issues. Unfortunately, the secondary material is divided by type, so books, dissertations, and journal articles are listed separately, which means that locating all relevant secondary material involves much browsing. This bibliography is particularly useful for its detailed listing of official literature, compiled by the author over a period of years, including visits to the headquarters at Bethel in the 1960s. As the author notes, many of these items are no longer accessible, and he discusses the difficulties involved in locating this material. All the more reason scholars will be grateful that this material has been documented.-M.C.

\section{Literature}

Moral, Rafael del. Enciclopedia de la novela española. Barcelona: Planeta, 1999. 712p. (ISBN 84-08-02666-6). LCCN 995162686.

This dictionary covers six centuries of Spanish narrative literature arranged alphabetically by novel title. A chronological table of fiction from the 1440s to 1998 enables the user to trace the history of Spanish fiction. A substantial bibliogra- 
phy (pp. 645-75) lists monographs and articles in specialized periodicals relating to literary criticism, surveys, literary history, theories, and commentaries on individual works of fiction. The author index, which lists the author's works with the date of publication and the index of characters, completes the volume.

The dictionary covers novels discussed in cited works of literary criticism and history and those titles that are regularly included in the programs of study in Spanish secondary schools and universities. For each title, bibliographic information (author, publication date, relation to other works of the author) is given along with a brief note on the theme, the author's purpose, outline of the story, critical evaluation, and a bibliography of commentaries and critical works (with full citation in the bibliography section). This is a handy guide to Spanish fiction and works on the genre.-J.S.

\section{Music}

Helander, Brock. The Rockin' '60s: The People Who Made the Music. New York: Schirmer, 1999. 461p. il. \$20 paper (ISBN 0-02-8648730). LCCN 98-49457.

A noted writer on rock music, Helander provides a "critical and historical discography of rock and soul music in the 1960s, covering major musical artists" (Pref.). Included are eighty-six entries for group performers, forty for individual performers, and about a dozen for individuals important to the rock scene during this time as songwriters, disc jockeys, record company founders, concert or record producers, and newspaper publishers. The author based this volume and a companion, The Rockin' '50s (New York: Schirmer, 1998), on his earlier publications on rock music.

Entries are listed alphabetically by name of group or last name of individual. Both individual and group entries contain birth and death dates, place of birth, name at birth, and performing medium, when applicable. The body of the entries has some biographical information, but, in general, the author focuses on describ- ing the creative and performing career of the subject.

The discographies aim at completeness and include record albums, cassettes, and compact discs that were regularly released in the Unites States on commercial labels. Foreign releases are excluded unless their record labels were normally distributed in this country. Discography entries are listed by date of recording, with anthology and compilation albums listed after individual album titles.

Bibliographies accompany individual entries, and an extensive bibliography covering thirty years of publications is provided. A detailed index of names and song/album titles enables the reader to locate individual personnel within performing groups, as well as individual songs from albums.

This volume provides solid discographical and bibliographical information and career summaries on the major figures in rock music during a seminal decade of its development.-E.D.

\section{Art}

Bénézit, Emmanuel. Dictionnaire critique et documentaire des peintres, sculpteurs, dessinateurs et graveurs de tous les temps et de tous les pays par un groupe d'écrivains spécialistes français et étrangers. Nouvelle éd., entièrement refondue sous la direction de Jacques Busse. Paris: Gründ, 1999. 14v. \$700 (ISBN 2-7000-3010-9).

This fourth edition of the French dictionary of international artists' biographies follows the pattern set in the previous editions with an ever-increasing number of volumes (from ten to fourteen), historical currency tables in volume one for use in determining auction price equivalencies for works of art listed in the artist entries, and the inclusion of artists' signatures and monograms.

Nearly 200,000 artists are included "from all times and all countries" (according to the title), but the emphasis remains primarily European. Each entry, which can run from as few as three lines to as many as fourteen columns (e.g., Picasso), 
is arranged alphabetically under a bold heading, with dates of birth and death, nationality, media and themes employed in the oeuvre (in slightly bolder type than the text to distinguish quickly the type of artist), followed by one or more paragraphs of narrative biography on chronology, training, description of the artist's work, analysis of style, and list of exhibitions. A monogram, signature, or bibliography may be included. Next is a listing of museums holding the artist's work, followed by a chronology of auction prices. Most entries are unsigned. At the end of each letter of the alphabet is a list of monograms of anonymous artists who have signed their work using that letter. A general bibliography completes the last volume.

Although not as comprehensive as the massive, but unfinished, Allgemeines Künstlerlexikon: die bildenden Künstler aller Zeiten und Völker (BF135), begun in 1983 and only completed as far as the letter $C$ after twenty-two volumes, Bénézit will continue to prove useful to those with a reading knowledge of the romance languages and, with ten times the number of biographies as the new Grove Dictionary of Art Online, reviewed below, is still required on art reference shelves.-B.S.A.

\section{Grove Dictionary of Art Online (text} [HTML] and graphics). London: Macmillan; New York: Grove's Dictionaries, (in progress). $\$ 1,500 /$ year online only; $\$ 1,000 /$ year with existing printed volumes. http:/ / www.groveart.com.

The online version of the printed 34volume Dictionary of Art, reviewed here in March 1997, is more than just a repackaging of the original. Its annual subscription price can be justified by the inclusion of new and revised articles (numbering just over 45,000 as of October 1999), access to 35,000 images via the Bridgeman Art Library (holdings from more than 800 museum and private collections, plus public art and architectural sites), 25,000 external image links, and links to 650 artrelated Web sites, all totaling well over
100,000 images by the end of 1999 , numbers that will continue to grow.

The schedule of online revisions involves a yearly review of at least six subject areas, which also will appear as printed supplements to the Dictionary of Art, arranged as encyclopedias for African, American, ancient, Asian, Australasia and European art, published collectively as the Grove Library of World Art. New bibliographical citations and contributors for the revised articles will be added to the database on a regular basis. Biographies will be updated with death dates for contemporary persons already in the Dictionary of Art, plus entries for new artists (fifty in the October update).

Currency and quality of the Web sites will be of particular interest to users of this feature. Links appear in sidebars alongside the text articles and as separate access points via the Bridgeman Library images and "interesting Websites" links on the home page. A quarterly review schedule by Dictionary staff to keep abreast of changes and additions to these sites has been initiated, along with the participation of the major image providers to maintain functionality. Image quality is consequently only as good as the providers' own sites and predictably ranges from good to poor to inaccessible, depending on copyright restrictions.

A search can be initiated from the home page on an artist or subject heading (i.e., article title) from the "article search" window but can lead to false hits or no results for more specific queries, such as individual works of art. Clicking on the "search" button, instead, provides the choice of either an article or full-text search and gives help on concept (synonyms, plurals), patterns (spelling variants), expert (weighted), and Boolean searching techniques for better results from a full-text search. In addition, there are options for highlighting text and explaining search results. After an article is found, a sidebar links to the external images, maps, charts and diagrams, and to abbreviations, related articles, a table of contents, and the bibliography. Searching 
directly for bibliographies and contributors is also possible from the search screen. The index can be searched or browsed alphabetically, and there is ample flexibility from the Excalibur search engine to allow for easy movement between screens and among multiplesearch results.

This is a growing and evolving product that will serve an ever-widening audience as it expands access to reliable art historical scholarship and convenient image location, truly an exemplar of the melding of electronic text and image that libraries now require and users are coming to expect.-B.S.-A.

\section{Photography}

McDarrah, Fred W. The Photography Encyclopedia. New York: Schirmer, 1999. 689p. il. \$80 (ISBN 0-02-865025-5). LCCN 98-46084.

Intended as "a comprehensive overview of the medium in a single, easy-to-use volume" (Introd.), this handsomely produced encyclopedia highlights current trends, techniques, and photographers. Similar in form to the 1984 edition of the ICP Encyclopedia of Photography (BF341), this volume focuses less on the history of the medium and more on the contemporary influences and contributors from the world of photography today.

Primarily consisting of biographical entries and definitions of photographic terminology, there is a notable emphasis on women photographers, younger photographers and conceptual artists whose work encompasses photography. Other contributors to the field, including curators, museum directors, archivists, collectors, critics, and historians, are included in individual entries as well. The entries are arranged alphabetically, with crossreferences noted in bold-faced type. Though brief, the biographical entries are often paired with full- or half-page blackand-white photographs, a fitting visual enhancement to the factual details of an artist's life and work.

An extensive appendix following the alphabetic entries covers everything from awards to American booksellers, galleries, and manufacturers to a time line of major dates in the development of photography. However, the end matter seems to be arranged in a somewhat haphazard fashion. It would have made more sense to arrange these sections by relative importance rather than alphabetically. For instance, the time line would be better suited at the beginning of the appendix than at the end.

The section entitled "Book Reviews" serves as the bibliography. Brief annotations are given for more than three hundred books on and about photography; however, one would have liked some editorial comment as to why these particular books were included in this section or some arrangement of them by subject or relevance.

These minor complaints aside, this encyclopedia is a valuable reference source for students of photography as well as for those interested in contemporary culture. Moreover, it is a rewarding book to browse through for its impressive selection of photographic images.A.M.

\section{Social Sciences}

Barbuto, Dominica M. American Settlement Houses and Progressive Social Reform: An Encyclopedia of the American Settlement Movement. Phoenix, Ariz.: Oryx, 1999. 270p. \$74.95 (ISBN 157356-146-0). LCCN 99-28054.

The author had several aims in mind in this coverage of the men and women, institutions, and events of the late nineteenth and early twentieth centuries. Besides a description of the more prominent settlement houses and their programs, she includes "explanations of the religious, social, or labor movements that influenced those involved in the settlements ..., social organizations that influenced or were influenced by the settlement movement ... , descriptions of the significant publications by individuals associated with the movement ... and of legislation relevant to the work" (Pref.). The 230 entries range from the National Housing Association, 
the Visiting Nurse Service, the National Civil Liberties Bureau, to Lewis Hine and Jacob Schiff and Olivia Hill, to the Pittsburgh Survey and How the Other Half Lives to Christian socialism and Dumbbell tenements. Of course, specific settlement houses such as Hiram House and Henry Street Settlement are treated, although not as many as one would have thought. The Children's Aid Society is included, but only within the article on Charles Loring Brace.

Each article has a summary with a brief bibliography citing standard sources such as the Encyclopedia of New York City (ed. Kenneth T. Jackson, New Haven: 1995), Notable American Women (AH66), and the Biographical Dictionary of Social Welfare in America (CC39). No primary sources are cited, which is a disappointment as there have been several recent surveys such as the NYC Settlement House Records Survey at LaGuardia Community College as well as the collecting initiatives at the University of Minnesota's Social Welfare History Archives.

The index is quite useful, with subheadings and cross-references, and there is a Bibliography of Printed Resources (pp. 241-45). Barbuto has produced a good starting point.-E.M.

Crawford, Elizabeth. The Women's Suffrage Movement: A Reference Guide, 1866-1928. London: UCL Pr., 1999. 785p. £110 (ISBN 1-84142-031-X).

This is a wonderful reference tool for researching the British women's suffrage movement. Entries are arranged alphabetically with an excellent balance between long, comprehensive entries on suffragists, organizations, and topics and brief entries for specific local chapters and committees. The entries are clear and well written. An interesting feature is the inclusion of contemporary street addresses (with dates and address changes) for individuals and organizations. Entries also provide bibliographies, the location of archives, and the existence of photographs.

The author reports that "most of the research for this reference source has been based on archival sources, relying as little as possible on secondary materials" (Introd.), a refreshing change from the recent plethora of Facts on File and ABCCLIO encyclopedias that do nothing more than repackage existing scholarship. In addition to the entries for some 400 suffragists and 800 societies, there are fascinating essays on a variety of subjects: china and silver; film (newsreels and feature films); jewelry and badges; libraries (with an interesting discussion of the library at Holloway where many suffragists were imprisoned); newspapers and journals; novels; postcards; and songs. Each essay includes extensive lists of primary source material for each genre.

Unfortunately, there is no index or list of topics so that librarians should take a minute to familiarize themselves with the wealth of information in the Reference Guide. Without doubt, it is the best women's studies reference book published in recent years and is recommended for all libraries supporting work in the British suffrage movements. Let us hope for a future volume covering the American women's suffrage movement.-S.S.W.

Encyclopedia of Violence, Peace and Conflict.

Ed. Lester Kurtz. San Diego, London:

Academic Pr., 1999. 3v. (2,175p.) il. \$625 (ISBN 0-12227010-X).

The Encyclopedia of Violence, Peace and Conflict is an ambitious work, superbly executed. Its purpose, as stated in the preface, is "to bring together in one place a broad range of information and perspectives on violence, peace, and conflict in order to enhance our understanding of these crucial phenomena and to stimulate new research, insights, and better public policies." It accomplishes this purpose by casting a wide net-admitting the broadest possible variety of definitions for the three concepts and drawing on scholarship from a broad spectrum of disciplines. With this all-encompassing scope, the editor hopes to provide a comprehensive picture of the current state of knowledge about violence, peace, and conflict, while 
admitting that that picture is only a snapshot of a rapidly changing area of inquiry.

The body of this three-volume work is composed of 196 articles covering such disparate topics as peace education, trends in warfare, cruelty toward animals, ethnic conflict, drug control policies, and child abuse. Each article begins with an outline that indicates its general content, followed by a glossary in which terms important to the understanding of the article are defined. The first paragraph always gives a definition of the topic under discussion and summarizes the content of the article. Access to the topics is manifold: first, through the alphabetical arrangement of articles by title, with a conscious effort to begin the title with a key word or phrase indicating the topic; second, through a list of articles arranged under fifteen subject areas into which the overall field of violence, peace, and conflict has been divided; third, through an exhaustive back-of-the-book subject index; and fourth, through cross-references within an article to related articles. A bibliography concludes each article entry.

It is clear that much thought has gone not only into the content, but also into the organization of the work. Comprehensiveness, diversity of viewpoint, scholarly rigor, clarity of presentation, and ease of access are the hallmarks of this encyclopedia. For this reason, it is of great value not only to students of the field, but also to practitioners and the generally curious.-O.d.C.

\section{New York Public Library African Ameri-}

can Desk Reference. New York: John Wiley and Sons, 1999. (Sponsored by the Schomburg Center for Research in Black Culture). 606p. il. \$34.95 (ISBN 0-471-23924-0).

The Schomburg Center for Research in Black Cultures of the New York Public Library is one of the foremost research libraries in the world on black history and culture, and its sponsorship of this latest New York Public Library desk reference work is significant. Intended for the general user, this desk reference provides current information on the important aspects of black life and culture. "It surveys the story of Africans in the Americas, including the Caribbean, from slavery through contemporary political and civil rights movements" (Foreword). The work is arranged by topical subject into nineteen parts. The topics include, among others, slavery and freedom, politics and civil rights, education, business, literature and language, and performing arts.

Although some sections offer an informative and diverse mix of text, data, charts, lists, and a bibliography; others are in need of more content and better editing. For example, the literature and language section includes a discussion of literary movements and provides a list of African-American winners of major literary prizes, African-American bookstores, publishers, literary organizations, and notable African-American writers. The performing arts section, which covers dance, theater, film, and television, follows a similar format but falls short of content. In addition, an entry for Spike Lee appears in the media section while his films are listed in the performing arts section. For additional sources on film, the readers must go to the media section, even though film is discussed in the performing arts section. This is confusing for the reader. Regardless, the work is filled with useful information and is recommended for any collection.-N.F.

\section{Business}

Kalorama Academic. Bethesda, Md.: Kalorama Information (in progress). www.marketresearch.com/kalorama. This database attempts to satisfy the need for full-text market research in the academic library. Because such full-text information is usually unaffordable, universities and colleges have had to be satisfied with out-of-date print reports on a limited number of subjects. This database is a subset of Kalorama's commercial catalog of market research reports. Although not extensive enough to be useful to everyone needing market research informa- 
tion, Kalorama Academic is a good basic resource for students and faculty for academic projects.

Kalorama Academic includes market research in twenty subject areas, such as beverages, food, office supplies, and telecommunications. Some of the subjects, such as personal care, have as many as twenty-three reports on different segments of that industry dated from 1995 to 1999 . Others have only one or two reports from different years. Although Kalorama Academic is inconsistent in size and coverage, it is a new database. The vendor has already added some reports and will continue to add more over the next year. The reports themselves are long and detailed, up to several hundred pages each. They can be viewed in PDF format, required Adobe Acrobat reader, or downloaded on a hard drive or disc. They differ in ease of navigation. Each is comprehensive, detailing the major player of an industry, sales figures, and market share in each sector and for each product. The search capabilities of the database are basic at best. The search engine indexes only words in the abstract. In addition, it will return reports that include one word and not the other. Although this is inconvenient, browsing the collection is easy.

Kalorama Academic is an affordable product that provides very detailed market research reports. Although it is not as comprehensive in subject matter or as timely as librarians would like, it should prove useful for both graduate and undergraduate students and faculty.-J.W.

\section{History}

Encyclopedia of Historians and Historical Writing. Ed. Kelly Boyd. London, Chicago: Fitzroy Dearborn, 1999. 2v. (1,562p.) \$270 (ISBN 1-884964-33-8). LC 98-193149.

This two-volume encyclopedia covers the history of historiography worldwide from the earliest time to the current, from Confucius and Herodotus to Eric Foner, Simon Schama, and the Australian feminist historian Marilyn Lake, who is the youngest of the distinguished historians included in these volumes. The work attempts to go beyond the "Western Historical Canon," exploring historical writings of all ages and all places through three types of essays. The first discusses individual historians with the emphasis on their scholarly works "in the context of historiographical developments and debates" (Editor's Note). The second type focuses on a specific nation or geographic area. And the third, topical essays, covers (1) subdisciplines of history such as economic history, (2) methods of historical inquiry from prosopography to the use of the computer, and (3) the most significant historical debates on topics such as the Industrial Revolution and slavery.

Entries are, in general, readable and informative; and each article is accompanied by a good bibliography. As for the people included in this reference work, some are not strictly historians but, rather, philosophers and thinkers who influenced historical writing, such as Clifford Geertz, the cultural anthropologist.

The encyclopedia is accompanied by an Alphabetical List of Entries, a Thematic List for Entries by Category, and a Chronological List of Historians. These lists, duplicated in both volumes, are useful for quick checking of the coverage and scope. Included, too, are the Title Index (index to titles of works cited in the articles), Further Reading Index (author/editor index to bibliographies that accompany articles), and Notes on Advisers and Contributors (brief notes on contributors' institutional affiliation and major works). On the whole, the encyclopedia is well indexed and easy to use whether you want to learn about an individual historian or the historiography of a country.J.S.

\section{New editions}

Two editions of standard desk dictionaries have been revised. Random House Webster's College Dictionary ( $2^{\text {nd }}$ Random House ed., 1999. 1,571p. \$24.95; $1^{\text {st }}$ ed. 1991. AC19; previously titled Random House College Dictionary) is a complete re- 
write of the definitions and the usage notes but still rarely gives derivation. New is a "ready reference" supplement with a Guide for Writers, Forms of Address, and a list of Words Most Often Misspelled and Words Commonly Confused. The chapter titled "Avoiding Sexist Language" is now titled "Avoiding Insensitive and Offensive Language."

Webster's New World College Dictionary, edited by Michael Agnes, is in its fourth college edition (New York: Macmillan, 1999.1,716p. \$21.95;3d ed. 1988. AC20) and has made great efforts to keep current; thus, we find the terms get go and ghetto blaster. The syllabification has been revised and is more sensible. The volume also has a reference supplement for maps, monetary units, the Constitution, populations of cities and countries, books of the Bible, a geologic time clock, and so on.

K.G. Saur, Munich, produced a twopart microfiche reprint called American Biographical Archive. Accompanying it now is a ten-volume American Biographical Index $x_{\llcorner}$compiled by Laureen Baillie (Munich: Saur, 1998) in a second cumulated and enlarged edition. These volumes can be used as a reference tool in their own right for verification, for brief biographical information, and as an index to one's own biographical dictionary collection. Saur also published the Deutsche biographische Enzyklopädiae ${ }_{\Perp}$ edited by Walther Killy (Munich, 19951999), whose alphabet has been completed with Band 10 covering ThibautZycha (711p.). Two volumes of indexes have been announced for publication in 1999-2000.

The Aslib Directory of Information Sources in the United Kingdom, compiled by Keith W. and Jeremy M.E. Reynard, is based on information "supplied by the organisations themselves in response to questionnaires and/or telephone inquiries" (Verso). This edition, the tenth, (London: Aslib, 1998. 1,505p. \$250; $9^{\text {th }}$ ed., 1996. AK141) adds five hundred entries, many of them dealing with local history. The indexing and the cross-references have been increased.
The first edition of the Cambridge Dictionary of Philosophy appeared in 1995, edited by Robert Audi. Now already there is a second edition, also edited by Audi (Cambridge University Press, 1999. 1,001p. \$74.95), with four hundred new entries including fifty on preeminent, contemporary philosophers. This volume has concentrated on rapidly developing fields such as bioethics; environmental, medical, and professional ethics; political philosophy; and non-Western philosophies. There is an appendix for special symbols and logical notations.

Volume 7 of the Encyclopedia of Indian Philosophies (1996. BB33) took up Buddhist philosophy in South Asia, with Abhidharma Buddhism to 150 AD and summarized texts of philosophical interest, theoretical and polemical. Now volume 8 continues the coverage of Buddhism with Buddhist Philosophy from 100 to 350 $A D$, edited by Karl H. Potter (Delhi: Motilal Banarsidass, 1999. 827p. R600).

The bibliographies in Slavery and Slaving in World History first appeared as annual installments in the journal, Slavery and Abolition, 1980-1996. The citations published 1900 through 1991 were compiled by Joseph C. Miller as Slavery and Slaving in World History, a Bibliography, 1900-1982 (Armonk, N.Y.: M.E. Sharpe, 1985. CC328). Citations from 1992 to 1996 are consolidated into what is now volume 2 of Slavery and Slaving in World History (1999. 244p. \$85). Notable is an increasing interest in literary output, for example, writing by the slaves themselves. A historiographical survey appears in the Introduction, pp. ix-xxi.

The revised and expanded edition of the Women's Studies Encyclopedia (Westport, Conn.: Greenwood, 1999. 3v. \$295) focuses on the American experience as did the first edition (1989-1991. CC537) but adds "more articles on contemporary conditions for women in specific countries or regions" (Introd.). Besides updating the articles, it offers greater coverage of women in public life and violence against women. A CD-ROM version is available from the publisher (\$295.00). 
Brian Mitchell has revised the International Historical Statistics: Europe (CG189), International Historical Statistics: The Americas (CG70) International Historical Statistics: Africa, Asia and Oceania (CG375) to update the time period to 1750-1993 (London: Macmillan Reference; New York: Stockton Pr., 1998. \$350 each). All volumes have dropped the section on climate and added statistics on money supply. Mitchell has made every effort to supply demographic statistics for the new countries evolving from Yugoslavia and the USSR from 1945 but has not always been successful.

Gallup has issued polls since October 20, 1935, and these have been cumulated into the Gallup Poll: Public Opinion, an annual presentation (CJ487) that has now reached twenty-five volumes. Alec $\mathrm{M}$. Gallup has indexed these volumes of polls into The Gallup Poll Cumulative Index: Public Opinion, 1935-1997 (Wilmington, Del.: Scholarly Resources, 1999. 596p. \$150). Under an index term the citation gives the year and page to the annual cumulation. The letter $t$ after the page number refers to an opinion trend.

George C. Kohn's Dictionary of Wars has grown to 1,800 entries, including descriptions of very current conflicts such as Chiapas, the Ethiopia and Eritrean Border War of 1998, Yugoslavia (New
York: Facts on File, 1999. 614p. \$75; 1986. DA24). It is still a brief descriptive treatment with no sources cited.

The Times History of the World, $5^{\text {th }}$ ed., edited by Richard Overy (London: Times Books, $1999.375 \mathrm{p} .37 \mathrm{~cm}$.) is the new name of The Times Atlas of World History_ $\left(4^{\text {th }} \mathrm{ed}\right.$. 1995. DA58). The maps are redrawn and recolored, there are more pictures, and the compiler has relied on digitized map making. The bibliography was updated to the mid-1990s.

Encyclopedia USA: The Encyclopedia of the United States of America Past and Present (DB47) has begun a supplement (Gulf Breeze, Fla.: Academic International Pr., 1997-1998. v.1-2). The publisher asserts that these articles treat current topics or came in too late for the original volumes. They expect a supplement volume to cover three letters of the alphabet; however, in Supplement II we have articles on AAUP; All Star Game; Americanism; Fran Allison; America, Naming of; Sadie Tanner Mosell Alexander. The table of contents is on the last few pages. In the main alphabet the coverage has reached to volume 26, 1999, which covers Education, Antebellum South to Ellis, Seth Hockett. Also new is Index Volume 2, which covers volumes 1120, 1989-1994 (1999. 248p.): Chickamauga and Chattanooga National Military Park to Detective Story. 